\title{
The relationships between height and arm span, mid-upper arm and waist circumferences and sum of four skinfolds in Ellisras rural children aged $8-18$ years
}

\author{
Kotsedi Daniel Monyeki* and Michael Matome Sekhotha \\ Department of Physiology and Environmental Health, University of Limpopo, Turfloop Campus, Private Bag X1 1o6, \\ Sovenga 0727, South Africa
}

Submitted 6 February 2015: Final revision received 20 June 2015: Accepted 5 August 2015: First published online 23 September 2015

\begin{abstract}
Objective: Height is required for the assessment of growth and nutritional status, as well as for predictions and standardization of physiological parameters. To determine whether arm span, mid-upper arm and waist circumferences and sum of four skinfolds can be used to predict height, the relationships between these anthropometric variables were assessed among Ellisras rural children aged 8-18 years. Design: The following parameters were measured according to the International Society for the Advancement of Kinathropometry: height, arm span, mid-upper arm circumference, waist circumference and four skinfolds (suprailiac, subscapular, triceps and biceps). Associations between the variables were assessed using Pearson correlation coefficients and linear regression models.

Setting: Ellisras Longitudinal Study (ELS), Limpopo Province, South Africa.

Subjects: Boys ( $n$ 911) and girls ( $n$ 858) aged $8-18$ years.

Results: Mean height was higher than arm span, with differences ranging from $4 \mathrm{~cm}$ to $11.5 \mathrm{~cm}$ between boys and girls. The correlation between height and arm span was high (ranging from 0.74 to 0.91 ) with $P<0.001$. The correlation between height and mid-upper arm circumference, waist circumference and sum of four skinfolds was low (ranging from 0.15 to 0.47 ) with $P<0.00$ among girls in the 15-18 years age group.

Conclusions: Arm span was found to be a good predictor of height. The sum of four skinfolds was significantly associated with height in the older age groups for girls, while waist circumference showed a negative significant association in the same groups.
\end{abstract}

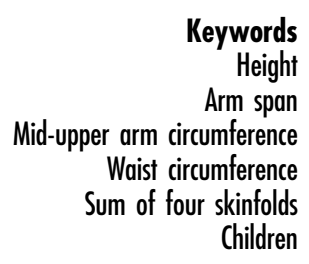

Height and body mass are important parameters to measure in the assessment of adiposity in children and adults $^{(1)}$. Given the well-documented limitations of BMI in the assessment of obesity, future basal metabolic risk and standardization of physiological parameters like muscle strength and glomerular filtration rate during human growth $^{(2,3)}$, waist circumference, mid-upper arm circumference (MUAC) and skinfold thickness are leading direct methods used to assess fat distribution ${ }^{(4,5)}$. There are established relationships between height and different body dimensions in adult human beings. The relationship between height and arm span is reported by some authors $^{(6-11)}$ while other studies have reported the estimation of height from arm span ${ }^{(12-15)}$. Furthermore, height has been estimated from the dimensions of upper and lower extremities $^{(9,16,17)}$. However, in the fracture of vertebrae or paralysis situation, measuring height is difficult ${ }^{(18)}$. In such a situation, measurements such as arm span, waist circumference, knee height, arm length, sitting height, MUAC and skinfold thickness could be used ${ }^{(3,5,19,20)}$ to assess height.

There are few studies showing the associations between height, MUAC and waist curcumference ${ }^{(11,17)}$. The purpose of the present study was to assess relationships between height and arm span, waist circumference, sum of four skinfold thicknesses and MUAC among Ellisras rural children aged 8-18 years.

\section{Methods}

\section{Geograpbical area}

The rural areas of Ellisras are situated in the north-western region of Limpopo Province, South Africa. Approximately 50000 people live there in forty-two settlements, which are $70 \mathrm{~km}$ from Ellisras town, now known as 
Lephalale, adjacent to the border with Botswana. Iscor coal mine and Matimba electricity power station are the two major sources of employment for many residents. The remaining workforce is involved in subsistence farming and cattle rearing, while a minority works in education or the civil service. Unemployment, poverty and low life expectancy seem to be more prevalent in this rural area ${ }^{(21)}$.

\section{Study population}

The Ellisras Longitudinal Study (ELS) initially followed a cluster sampling method described previously by Monyeki et $a l^{(22)}$. In brief, the study was undertaken at twenty-two schools (ten pre-schools and twelve primary schools) randomly selected from sixty-eight schools within Ellisras area $^{(23)}$. For the purpose of the present analysis, data collected in November 2003 were used. The sample population comprised 1769 children (911 boys, 858 girls) aged 8-18 years.

The Ethics Committee of the University of Limpopo (Turfloop Branch) granted ethical approval prior to the survey and parents or guardians provided informed consent. The children and their parents signed assent forms after receiving verbal assent, which were translated into their mother tongue by the project's principal investigator.

\section{Antbropometrics}

All children underwent a series of anthropometric measurements according to the International Society for the Advancement of Kinanthropometry. Body mass was measured on an electronic scale to the nearest $0.1 \mathrm{~kg}$. A Martin anthropometer was used to measure height to the nearest $0 \cdot 1 \mathrm{~cm}$. Skinfolds (suprailiac, subscapular, triceps and biceps) were measured three times using a Slim Guide skinfold calliper. Waist circumference and MUAC were measured with a flexible steel tape to the nearest $0.1 \mathrm{~cm}$. Waist circumference was measured laterally midway between the lowest portion of the rib cage and the iliac crest, and anteriorly midway between the xiphoid process of the sternum and the umbilicus. Arm span was measured by positioning the participant's back against the wall with his/her arms spread against the wall at shoulder level and parallel to the floor with the palms facing forward. A steel tape was used to measure from the tip of the middle finger on one hand across the chest to the tip of the middle finger on other hand $^{(24)}$. Participants below 8 years of age and above 18 years of age were of limited number. In order to make a meaningful conclusion to the study, participants were placed into age groups of 8-10 years, $11-14$ years and $15-18$ years.

\section{Quality control}

Training of all anthropometric measurements was done in compliance with standard procedures of the International Society for the Advancement of Kinanthropometry ${ }^{(24)}$. Reliability and validity of the anthropometric measurements are reported elsewhere ${ }^{(23)}$. In brief, the absolute and relative values for intra- and inter-tester technical error of measurement ranged from 0.04 to $4 \cdot 16 \mathrm{~cm}(0 \cdot 2$ to $5 \cdot 0 \%)$ for height, from 0.01 to $0.02 \mathrm{~kg}$ (0 to $0.3 \%$ ) for body mass, from 0.2 to $6.0 \mathrm{~mm}(0.4$ to $6.8 \%)$ for skinfold measurements, and from 0 to $3.4 \mathrm{~cm}$ ( 0 to $4 \%$ ) for arm span and girth measurements (waist and MUAC).

\section{Statistical analysis}

Descriptive statistics were calculated for absolute body size. Student's $t$ test was applied to test for significant differences between sexes. Pearson correlation coefficients were calculated to assess associations between height and arm span, waist circumference, MUAC and sum of the four skinfold thicknesses. Linear regression models were used to assess relationships between height and age, arm span, MUAC, waist circumference and sum of four skinfolds. All statistical analyses were done using the statistical software package SPSS version 10. The statistical significance was set at $P<0.05$.

\section{Results}

Table 1 presents the descriptive statistics for age and anthropometric measurements of Ellisras rural children aged 8-18 years. Ellisras rural girls the age group of 11-15 years showed significantly higher mean values than boys for height, arm span, MUAC and waist circumference (all $P<0.001)$. Sum of four skinfolds was significantly $(P<0.05)$ higher in girls (range from 26.2 to $40.4 \mathrm{~mm}$ ) than in boys (range from 24.0 to $26.2 \mathrm{~mm}$ ) throughout all age groups. Mean height (range from 137.6 to $162 \cdot 2 \mathrm{~cm}$ ) was found to be higher than arm span (range from 125.7 to $157.4 \mathrm{~cm}$ ) throughout all age groups for both Ellisras rural boys and girls, with the differences ranging from 4.0 to $11.5 \mathrm{~cm}$.

Height and arm span showed a highly significant $(P<0.001)$ relationship (correlation coefficient ranging from 0.74 to 0.91 ) in both boys and girls throughout the age range (Table 2). The correlation between height and MUAC, waist circumference and sum of four skinfolds was low and significant $(P<0.05)$ in both Ellisras boys and girls, decreasing in magnitude in the older age group (correlation coefficient ranging from 0.15 to 0.47 ). The correlation (correlation coefficient ranging from 0.15 to $0 \cdot 29)$ between height and sum of four skinfolds was low and significant $(P<0 \cdot 001)$ in the older age groups $(11-18$ years). The correlation between height and age was not significant in the age group 8-10 years and 15-18 years for boys, while for girls in all age groups it was significant $(P<0 \cdot 05$; Table 2).

Table 3 illustrates the linear regression analysis of various anthropometric measurements and age as predictors of height for Ellisras rural children aged 8-18 years. The coefficient of determination of the models was high in the age group $8-10$ years ( $84 \%$ for boys and $75 \%$ for girls) and $11-14$ years ( $83 \%$ for boys and $75 \%$ for girls) and 
Table 1 Descriptive statistics for age and anthropometric measurements of Ellisras rural children aged 8-18 years, Limpopo Province, South Africa, November 2003

\begin{tabular}{|c|c|c|c|c|c|c|c|c|c|c|c|c|}
\hline & \multicolumn{4}{|c|}{$8-10$ years } & \multicolumn{4}{|c|}{$11-14$ years } & \multicolumn{4}{|c|}{$15-18$ years } \\
\hline & \multicolumn{2}{|c|}{ Boys ( $n$ 85) } & \multicolumn{2}{|c|}{ Girls ( $n$ 68) } & \multicolumn{2}{|c|}{ Boys (n 516) } & \multicolumn{2}{|c|}{ Girls ( $n$ 492) } & \multicolumn{2}{|c|}{ Boys $(n 310)$} & \multicolumn{2}{|c|}{ Girls (n 298) } \\
\hline & Mean & SD & Mean & SD & Mean & SD & Mean & SD & Mean & SD & Mean & SD \\
\hline Age (years) & $10 \cdot 2$ & 0.59 & $10 \cdot 3$ & 0.51 & $13 \cdot 3$ & 1.13 & $13 \cdot 3$ & 1.13 & $15 \cdot 9$ & 0.60 & $15 \cdot 9$ & 0.62 \\
\hline Height $(\mathrm{cm})$ & 137.6 & $7 \cdot 12$ & $137 \cdot 2$ & 7.46 & $151 \cdot 0^{\star \star}$ & $9 \cdot 25$ & $153 \cdot 2^{\star \star}$ & 8.62 & $162 \cdot 2$ & $9 \cdot 10$ & $161 \cdot 4$ & $6 \cdot 32$ \\
\hline Arm span (cm) & $127 \cdot 2$ & 8.67 & $125 \cdot 7$ & 7.97 & $142 \cdot 6^{\star *}$ & $10 \cdot 30$ & $145 \cdot 1^{* *}$ & $10 \cdot 55$ & $155 \cdot 8^{\star *}$ & $10 \cdot 40$ & $157 \cdot 4^{\star \star}$ & 8.02 \\
\hline Height - arm span (cm) & $10 \cdot 4$ & $3 \cdot 70$ & 11.5 & 4.06 & 8.4 & $4 \cdot 30$ & $8 \cdot 1$ & $5 \cdot 27$ & $6 \cdot 4^{\star \star}$ & 6.90 & $4 \cdot 0^{\star \star}$ & 5.41 \\
\hline MUAC $(\mathrm{cm})$ & $16 \cdot 7$ & 1.26 & $16 \cdot 8$ & 1.72 & $18 \cdot 3^{\star \star}$ & 1.69 & $19 \cdot 3^{\star *}$ & $2 \cdot 25$ & $20 \cdot 0^{\star}$ & $2 \cdot 19$ & $21 \cdot 2^{\star}$ & $2 \cdot 37$ \\
\hline Waist circumference (cm) & 53.8 & 3.02 & $52 \cdot 9$ & 3.48 & $57 \cdot 6^{\star \star}$ & 4.47 & $58 \cdot 1^{\star \star}$ & $5 \cdot 10$ & 61.5 & 4.50 & $62 \cdot 1$ & 5.47 \\
\hline Sum of four skinfolds $(\mathrm{mm}) \dagger$ & $24 \cdot 0^{\star}$ & $5 \cdot 04$ & $26 \cdot 2^{*}$ & $7 \cdot 86$ & $25 \cdot 3^{\star *}$ & 6.98 & $34 \cdot 1^{\star *}$ & 12.06 & $26 \cdot 2^{\star \star}$ & $8 \cdot 30$ & $40 \cdot 4^{\star \star}$ & $14 \cdot 33$ \\
\hline
\end{tabular}

MUAC, mid-upper arm circumference.

${ }^{\star} P<0.05,{ }^{* \star} P<0.001$.

†Sum of triceps, biceps, suprailiac and subscapular.

Table 2 Pearson correlation coefficients between height and age and other anthropometric variables of Ellisras rural children aged 8-18 years, Limpopo Province, South Africa, November 2003

\begin{tabular}{|c|c|c|c|c|c|c|}
\hline & \multicolumn{2}{|c|}{$8-10$ years } & \multicolumn{2}{|c|}{$11-14$ years } & \multicolumn{2}{|c|}{$15-18$ years } \\
\hline & Boys & Girls & Boys & Girls & Boys & Girls \\
\hline Age & 0.10 & $0.28^{*}$ & $0.64^{\star \star}$ & $0.61^{*}$ & 0.11 & $0.16^{\star \star}$ \\
\hline Arm span & $0.91^{\star \star}$ & $0.86^{\star \star}$ & $0.91^{\star \star}$ & $0.87^{\star \star}$ & $0.76^{\star *}$ & $0.74^{\star \star}$ \\
\hline MUAC & $0.56^{\star \star}$ & $0.87^{\star *}$ & $0.54^{\star \star}$ & $0.49^{\star \star}$ & $0.47^{* *}$ & $0.26^{\star \star}$ \\
\hline Waist circumference & $0.56^{\star \star}$ & $0.53^{\star \star}$ & $0.48^{\star \star}$ & $0.46^{\star *}$ & $0.46^{\star *}$ & $0.23^{* *}$ \\
\hline Sum of four skinfolds & 0.18 & $0.29^{\star}$ & $0.15^{\star \star}$ & $0.29^{\star \star}$ & $0.16^{\star *}$ & $0.15^{\star \star}$ \\
\hline
\end{tabular}

MUAC, mid-upper arm circumference.

${ }^{*} P<0.05,{ }^{* *} P<0.001$.

Table 3 Linear regression analysis of various anthropometric measurements and age as a predictor of height for Ellisras rural children aged 8-18 years, Limpopo Province, South Africa, November 2003

\begin{tabular}{|c|c|c|c|c|c|c|c|c|c|c|c|c|}
\hline & \multicolumn{4}{|c|}{$8-10$ years } & \multicolumn{4}{|c|}{$11-14$ years } & \multicolumn{4}{|c|}{ 15-18years } \\
\hline & $\beta$ & $R^{2}$ & SEE & $95 \% \mathrm{Cl}$ & $\beta$ & $R^{2}$ & SEE & $95 \% \mathrm{Cl}$ & $\beta$ & $R^{2}$ & SEE & $95 \% \mathrm{Cl}$ \\
\hline \multicolumn{13}{|l|}{ Boys } \\
\hline Intercept & $41 \cdot 20^{\star \star}$ & 0.84 & 2.97 & $24.90,57.40$ & $32 \cdot 10$ & 0.83 & 3.80 & $26 \cdot 95,37.34$ & $74.01^{\star \star}$ & 0.59 & 5.93 & $54.61,93.41$ \\
\hline Age & -0.659 & & & $-1.80,0.50$ & $0.687^{\star *}$ & & & $0.30,1.07$ & $-1 \cdot 152^{*}$ & & & $-2 \cdot 30,-0.01$ \\
\hline Arm span & $0.702^{* *}$ & & & $0.61,0.80$ & $0.740^{\star *}$ & & & $0.69,0.79$ & $0.641^{*}$ & & & $0.56,0.72$ \\
\hline Waist circumference & 0.074 & & & $-0.21,0.36$ & -0.052 & & & $-0.15,0.05$ & -0.011 & & & $-0.27,0.25$ \\
\hline MUAC & 0.588 & & & $-0.13,1.30$ & $0.497^{\star *}$ & & & $0.17,0.82$ & 0.386 & & & $-0.18,0.95$ \\
\hline Sum of four skinfolds & 0.002 & & & $-0.14,0.14$ & $-0.076^{\star}$ & & & $-0.14,-0.02$ & -0.017 & & & $-0.12,0.09$ \\
\hline \multicolumn{13}{|l|}{ Girls } \\
\hline Intercept & $39 \cdot 75^{\star *}$ & 0.75 & 3.37 & $17 \cdot 06,62 \cdot 43$ & $52 \cdot 21^{\star *}$ & 0.75 & $4 \cdot 30$ & $46 \cdot 14,58 \cdot 29$ & $64 \cdot 29^{* *}$ & 0.56 & $4 \cdot 21$ & $49.56,79.03$ \\
\hline Age & -0.538 & & & $-2.47,1.40$ & -0.023 & & & $-0.50,0.46$ & $0.705^{\star}$ & & & $-0.09,1.50$ \\
\hline Arm span & $0.755^{\star \star}$ & & & $0.61,0.90$ & $0.723^{\star \star}$ & & & $0.66,0.78$ & $0.615^{\star *}$ & & & $0.55,0.68$ \\
\hline Waist circumference & -0.144 & & & $-0.56,0.27$ & -0.093 & & & $-0.22,0.03$ & $-0.177^{\star}$ & & & $-0.32,-0.04$ \\
\hline MUAC & $0.995^{\star}$ & & & $0.08,1.91$ & 0.086 & & & $-0.25,0.42$ & -0.116 & & & $-0.48,0.25$ \\
\hline Sum of four skinfolds & -0.040 & & & $-0.19,0.11$ & 0.006 & & & $-0.04,0.06$ & $0.063^{*}$ & & & $0.01,0.12$ \\
\hline
\end{tabular}

SEE, standard error of the estimate; MUAC, mid-upper arm circumference.

${ }^{\star} P<0.05,{ }^{\star \star} P<0.001$.

decreased in the 15-18 years age group for both boys (59\%) and girls (56\%). Arm span was a significant $(P<0.001$ or $P<0.05)$ predictor of height in all the age groups for both boys and girls, ranging from $\beta=0.615$ (95\% CI $0.55,0.68)$ to $\beta=0.755$ (95\% CI $0.69,0.90)$. Waist circumference, with a range from $\beta=-0.144$ (95\% CI $-0.56,0 \cdot 27)$ to $\beta=-0.177$ (95\% CI $-0.32,-0 \cdot 04)$, and sum of four skinfolds, ranging from $\beta=-0.040$ (95\% CI $-0 \cdot 19$, $0 \cdot 11$ ) to $\beta=0.063$ (95\% CI $0.01,0.12$ ), were statistically significant $(P<0.05)$ predictors of height in the $15-18$ years age group for girls. MUAC, with $\beta=0.497$ (95\% CI $0 \cdot 17,0.82)$, and sum of four skinfolds, with $\beta=-0.076$ (95\% CI $-0.14,-0.02)$, were significant $(P<0.05)$ predictors of height in the 11-14 years age group for 
boys (Table 3). Waist circumference was not a statistically significant predictor of height among boys in all the age groups.

\section{Discussion}

The present study was aimed at assessing the relationship between height and other anthropometric parameters of schoolchildren from rural areas of Ellisras, South Africa. Linear regression analysis revealed that arm span was a significant $(P<0.05)$ predictor of height in all age groups, while MUAC and sum of four skinfolds significantly predicted height in the 11-14 years age group for Ellisras boys. However, age could predict height in the 8-10 years age group for both boys and girls. Similar results were reported for Dhimals in West Bengal, India for children aged $10-18$ years $^{(7)}$.

Longer mean height than arm span among Ellisras rural children was recorded in present study. Similar results were reported by Lucia et al. ${ }^{(6)}$ for the four ethnic groups Oromo, Ambara, Tigre and Somali in Ethiopia. Furthermore, Yabanci et al. ${ }^{(10)}$ reported shorter arm span compared with height among Turkish children aged 7-14 years. The results of the present study exhibit different trends from earlier reports. In Malawian children and Indian children arm span was found to be higher than height $^{(7,11,25)}$.

A significant strong correlation was recorded between height and arm span, waist circumference, MUAC and sum of four skinfolds in the present study among boys and girls. Similar trends were reported among Turkish children aged 7-14 years for height, arm span and MUAC ${ }^{(10)}$. In other studies too, height and arm span were reported to be strongly correlated ${ }^{(11,12,26)}$.

Arm span was found to be an impressive predictor of height in the present study. Sum of four skinfolds was a significant $(P<0.05)$ positive predictor of height in the $15-$ 18 years age group while waist circumference significantly $(P<0.05)$ negatively predicted height in the same age group for girls. Yabanci et $a l^{(10)}$ reported MUAC to be a predictor of height in the age group 7-10 years, while waist circumference was not a predictor of height for both sexes. Even though sitting height was reported to be a better predictor of total $\mathrm{BMI}^{(1,26)}$, there has been no study showing the correlation between height and sum of four skinfolds.

The findings of the ELS do not differ with other investigations worldwide. In Montenegrins the use of arm span was very effective to determine the height of female and male communities in the surrounding areas, even though it may differ in ethnic and racial groups ${ }^{(18,27)}$. In all of the estimations of body height from various anthropometric measurements it is important to emphasize that arm span has been the most reliable indicator for predicting the body height of an individual ${ }^{(28)}$. Arm span can be a reliable method used to measure height for disabled, old aged and deformed individuals ${ }^{(11,29)}$. A study by Yabanci et $a l .{ }^{(10)}$ stated that MUAC and waist circumference were found to be moderately correlated with height, while previous work recommended the use of MUAC as a criterion standard that can be used to estimate height ${ }^{(30)}$. Others have argued that neither MUAC nor skinfold thickness has a good relationship ability with height ${ }^{(31)}$.

\section{Conclusion}

In conclusion, arm span was found to be strongly related to height in schoolchildren aged 8-18 years from rural areas of Ellisras, South Africa, as reported in many studies. Sum of four skinfolds and waist circumference were found to be significantly associated with height in the older age group for girls. With waist circumference, however, the association was negative.

\section{Acknowledgements}

Acknowledgements: The authors are indebted to the ELS administrators (P.S. Seleka and T.T. Makata) for providing technical support in preparation of this manuscript. Financial support: This work was supported by the Vrije University, Amsterdam, The Netherlands (grant number UNIN Health Project under VUA Foundation funds) and the University of the North, South Africa (grant number 1404); the National Research Foundation (grant number URD2002050400168) for the Ellisras Longitudinal Growth and Health study is also acknowledged with gratitude. Any opinions, findings and conclusions or recommendations expressed in this material are those of the authors, and therefore the above-mentioned funding sources do not accept any liability in regard thereto. Conflict of interest: None. Authorship: K.D.M. was responsible for study design, data collection, data analysis and write-up. M.M.S. was responsible for data analysis and write-up. Ethics of buman subject participation: This study was conducted according to the guidelines laid down in the Declaration of Helsinki and all procedures involving human subjects/patients were approved by the University of Limpopo (Turfloop Campus). Written informed consent was obtained from all subjects/patients.

\section{References}

1. Burton RF (2015) Sitting height as a better predictor of body mass than total height and (body mass)/(sitting height $)^{3}$ as an index of build. Ann Hum Biol 42, 210-214.

2. World Health Organization (1995) Physical Status: The Use and Interpretation of Anthropometry. Report of a WHO Expert Committee. WHO Technical Report Series no. 854. Geneva: WHO.

3. Kemper HCG (2004) Amsterdam Growth and Health Longitudinal Study: A 23-Year Follow-Up from Teenager to Adult about Lifestyle and Health. New York: Karger Press. 
4. Cook S, Weitzman M, Auinger P et al. (2003) Prevalence of a metabolic syndrome phenotype in adolescents. Arch Pediatr Adolesc Med 157, 821-827.

5. Cameron N (2013) Essential anthropometry: baseline anthropometric method for human biologists in laboratory and field situation. Am J Hum Biol 25, 291-299.

6. Lucia E, Lemma F, Tesfaye F et al. (2002) The use of arm span measurements to assess nutritional status of adults in four Ethiopian ethnic groups. Eur J Clin Nutr 56, 91-95.

7. Banik SD (2011) Arm span as a proxy measure for height and estimation of nutritional status: a study among Dhimals of Darjeeling in West Bengal, India. Ann Hum Biol 38, 728-735.

8. Golshan M, Amra B \& Hoghoghi M (2003) Is arm span an accurate measure of height to predict pulmonary function parameters? Monaldi Arch Chest Sis 59, 189-192.

9. Ozaslan A, Ozaslan I \& Tugcu H (2006) Estimation of stature from upper extremity. Mil Med 171, 288-291.

10. Yabanci N, Killic S \& Simesek I (2010) The relationship between height and arm span, mid upper arm and waist circumference in children. Ann Hum Biol 37, 70-75.

11. Yousafzai AK, Filteau SM, Wirz SL et al. (2003) Comparison of armspan, arm length and tibia length as predictor of actual height of disabled and disabled children in Dharavi, Mumbai, India. Eur Clin Nutr 57, 1230-1234.

12. Zverev Y \& Chisi J (2005) Estimating height from arm span measurement in Malawian children. Coll Anthropl 29, 469-473.

13. Aggarwal AN, Gupta D, Ezekiel LM et al. (2000) Statistical estimation of height from arm span in north Indian subjects. J Physiol Pharmacol 44, 329-334.

14. Zverev Y (2003) Relationship between arm span and stature in Malawian adults. Ann Hum Biol 30, 739-743.

15. Ofluoglu D, Unlu F \& Akyuz G (2008) Relationship between arm span and height in post-menopausal osteoporotic women. Rheumatol Int 28, 737-741.

16. Agnihotri AK, Agnihotri S, Jeebun N et al. (2008) Prediction of stature using hand dimension. J Forensic Leg Med 15, 479-482.

17. Krishan K, Kanchan T \& DiMaggio JA (2010) A study of limb asymmetry and its effect on estimation of stature in forensic case work. Forensic Sci Int 181, 52.e1-e6.

18. Brown JK, Feng JY \& Knapp TR (2002) Is self-reported height or arm span a more accurate alternative measure of height? Clin Nur Res 11, 417-432.
19. Ozer BK, Gultekin T \& Sagir M (2007) Estimation of stature in Turkish adults using knee heights. Anthropol Anz 64, 213-222.

20. Gauld LM, Kappers J, Carlin JB et al. (2004) Height prediction from ulna length. Dev Med Child Neurol 46, 475-480.

21. Monyeki KD, Monyeki M, Brits SJ et al. (2008) Development and tracking of body mass index from preschool age into adolescence in rural South African children: Ellisras Longitudinal Growth and Health Study. J Health Popul Nutr 4, 405-417.

22. Monyeki KD, Cameron N \& Getz B (2000) Growth and nutritional status of rural South African children 3-10 years old: the Ellisras Growth Study. Am J Hum Biol 12, 42-49.

23. Monyeki KD, de Ridder JH, Steyn NP et al. (2002) Stability of somatotypes in 4 to 10 year-old rural South African girls. Ann Hum Biol 29, 37-49.

24. Norton K \& Olds T (1996) Anthropometrica. Sydney: University of New South Wales Press.

25. Tores LA, Martinez FE \& Manqo JC (2003) Correlation between standing height, sitting height and arm span as an index of pulmonary function in 6-10 year old children. Pediatr Pulmonol 36, 202-208.

26. Marcato DG, Sampalo JD, Alves ERB et al. (2014) Sittingheight measures are related to body mass index and blood pressure in children. Arq Bras Endocrinol Metab 58, 802-806.

27. Coon CS (1975) The Races of Europe, p. 18. Westport, CT: Greenwood Press.

28. Mohanty SP, Suresh B \& Sreekumaran N (2001) The use of arm span as a predictor of height: a study of South Indian women. $J$ Orthop Surg 9, 19-23.

29. Hickson $M \&$ Frost $G$ (2003) A comparison of three methods of estimating height in the acutely ill elderly population. J Hum Nutr Diet 16, 13-20.

30. Mozumdar A \& Roy SK (2004) Method for estimating body weight in person with lower limb amputation and it implications for their nutritional assessment. Am J Clin Nutr 80, 868-875.

31. Burden ST, Stoppard E, Shaffer J et al. (2005) Can we use mid upper arm anthropometry to detect malnutrition in medical inpatients? A validation study. J Hum Nutr Diet 18, 287-294. 